We may specially refer to his monograph on The Fauna of the Lower Cambrian or Olenellus Zone, 1890, and to the large series of memoirs on Cambrian Geology and Palaeontology, writings of high importance and embodying the results of a prodigious a mount of work.

It was fortunate that Walcott was able to pursue his detailed studies on the Mt. Stephen formation of British Columbia, one horizon in which may well be described as the "Solenhofen slate" of the Lower Palaeozoic period, so beautifully are its organisms preserved, and the work thereon will be of incalculable benefit to geologists and biologists alike.

Walcott was a man of commanding presence and magnificent physique. His friendship was a possession of which to be proud. He was a genuine lover of nature, evidence of which is furnished both by his published works and his private correspondence. In the study of the Cambrian System he forms one of a great trioSedgwick, Barrande, Walcott, and his name will ever be enrolled in the list of the world's great geologists.

J. E. M.

\title{
Leslie D. Currie, B.Sc.
}

BORN 19TH APRIL, 1904.

DIED 9TH NOVEMBER, 1925.

We regret to announce the death of Leslie D. Currie, who was drowned while bathing in Burma. Mr. Currie, after a brilliant career at Glasgow University, had just joined the staff of the Burma Oil Company as palaeontologist. After completing his degree he spent twelve months on research work on some undescribed Crustacea from the Silurian rocks of Lesmahago. A paper on a new Xiphosuran is published in this Magazine, but his main work on another series was still incomplete. By his death palaeontology has lost a very promising worker.

J. W. G. 